\title{
Analysis of Correlation between Workload and Work Attitudes Toward Work Fatigue (Case Study in Kaliotik Lamongan Restaurant Workers)
}

\author{
Analisis Hubungan Beban Kerja dan Sikap Kerja dengan Kelelahan Kerja \\ (Studi Kasus pada Pekerja Resto Kaliotik Lamongan)
}

\author{
Rohmia Fina Ansori \\ PT Inti Karya Jaya Perkasa \\ Jalan Outer Ring Road Tambak Boyo-Deket No. 07 Tikung, Lamongan, East Java 62281, Indonesia
}

\begin{abstract}
Introduction: Currently, Culinary becomes a promising business, so does Lamongan Kaliotik Resto, one of the famous restaurant in Lamongan. The high number of customer visits risks the workforce from work fatigue. The demand for production in order to fulfill the consumer needs leads to an excessive workload which is handed to the workers in the Kaliotik Lamongan restaurant. Moreover, high mobility in the food production process potentially creates non-ergonomic work attitudes. Therefore, all of those factors can lead the workers experiencing work fatigue. The purpose of this study was to analyze the relationship between workload and work attitude with work fatigue at Kaliotik Lamongan Resto workers. Methods: This study was observational descriptive which was done by using cross-sectional. The population in this study was all workers at the Kaliotik Lamongan Resto, which consisted of 13 people who worked in the kitchen and cashier kitchen section. The sampling technique used was the total population technique. Data collection includes physical workload measurements, assessment of work attitude with The Rapid Upper Limb Assessment (RULA) method and work fatigue measurements using a reaction timer. The study was analyzed using the Spearman correlation test. Results: Showed that the workload with work fatigue had a relationship with the strength of the moderate relationship $(r=0.415)$ and work attitudes with work fatigue showed a low strong relationship $(r=0.389)$. Conclusion: Excessive workload is the main factor which causes work fatigue in workers, in contrary, work attitude is not a factor of work fatigue.
\end{abstract}

Keywords: physical workload, work attitude, work fatigue

ABSTRAK

Pendahuluan: Bisnis Kuliner merupakan usaha yang menjanjikan di era saat ini, Resto Kaliotik Lamongan merupakan tempat usaha yang bergerak di bidang kuliner di kota Lamongan. Tingginya angka kunjungan pelanggan membuat tenaga kerja berisiko mengalami kelelahan kerja. Tuntutan produksi untuk memenuhi kebutuhan konsumen menyebabkan tenaga kerja pada resto Kaliotik Lamongan memiliki beban kerja yang cukup berat, mobilitas yang tinggi pada tenaga kerja dalam proses produksi makanan juga dapat menciptakan sikap kerja yang tidak ergonomis, semua hal tersebut dapat menimbulkan kelelahan kerja. Tujuan penelitian ini adalah untuk menganalisis hubungan beban kerja dan sikap kerja dengan kelelahan kerja pada pekerja Resto Kaliotik Lamongan. Metode: Penelitian ini adalah penelitian observational deskriptif dengan pendekatan cross sectional. Populasi dalam penelitan ini adalah seluruh pekerja di Resto Kaliotik Lamongan yang berjumlah 13 orang yang bekerja pada bagian dapur pramusaji dan kasir. Teknik sampling yang digunakan adalah teknik total populasi.. Pengumpulan data meliputi pengukuran beban kerja fisik, penilaian sikap kerja dengan metode The Rapid Upper Limb Assessment (RULA) dan pengukuran kelelahan kerja dengan alat reaction timer. Penelitian dianalisis dengan menggunakan uji korelasi spearman. Hasil: Penelitian menunjukkan antara beban kerja dengan kelelahan kerja memiliki hubungan dengan kekuatan hubungan yang sedang $(r=0,415)$ dan antara sikap kerja dengan kelelahan kerja menunjukkan kuat hubungan yang rendah $(r=0,389)$. Simpulan: Beban kerja yang berlebihan merupakan faktor utama yang dapat menyebabkan terjadinya kelelahan kerja pada pekerja, sedangkan sikap kerja bukan menjadi faktor penyebab kelelahan kerja.

Kata kunci: beban kerja fisik, kelelahan kerja, sikap kerja

Author for Correspondence:

Rohmia Fina Ansori

Email: rohmia.ansori@gmail.com

Telephone: +6282143198281

C2020 IJOSH. Open access under CC BY NC-SA license doi: 10.20473/ijosh.v9i1.2020.48-54. Received January 18, 2019, received in revised form March 15, 2019, Accepted April 13, 2020, Published: April 2020 


\section{INTRODUCTION}

Work exhaustion is one of the safety and health problems which can cause workplace accidents to workers. Work exhaustion consists of mental fatigue and physical fatigue, there are various factors that influence work fatigue, including physical work activities, mental work activities, non-ergonomic workstations, forced attitudes, static work, monotony work, extreme work environment, psychological factors, unmet calorie needs, unequal work time and rest periods. Work Exhaustion on labor can lead to a decreased of work motivation, low quality work, stress due to work, and decreased productivity. Factors above can cause work accidents (Tarwaka, 2015).

Based on data of Ministry of Manpower and Transmigration in 2004, the average of the work accidents in Indonesia per day is around 414 cases, and $27.8 \%$ of them are caused by workers who are experiencing high fatigue. Data compiled by the International Labor Organization (ILO) states that approximately two million workers die from workplace accidents every year caused by workers who experience work fatigue. Research conducted by the International Labor Organization (ILO) states that out of 58115 samples, around 18828 or $32.8 \%$ of the samples suffered from fatigue and affected their productivity (Atiqoh, Wahyuni and Lestyanto, 2014).

The occurrence of work fatigue is influenced by various factors, one of them is a physical workload. If the physical workload borne by the worker does not match his/her physical capacity; it will accelerate the occurrence of work fatigue. This is in accordance with the research conducted by (Maharja, 2015)(Maharja, 2015) toward nurses at the inpatient installation of Surabaya Hajj Hospital. The results of the study indicated that there was a strong relationship between nurses who had heavy workloads and nurses who experienced high work fatigue.

Non-ergonomic work attitude factors will accelerate the onset of work fatigue and lead to musculoskeletal disorders. This statement is supported by the research which was conducted by Yuslistyari, et al (2018), The research was analyzing JKS snack and catering industry home workers in Serang Banten, resulting from that in the production and packaging section there are non-ergonomic working attitudes which resulting work fatigue.
Based on several previous studies, workload and work attitudes are part of the factors that cause work fatigue. Work fatigue is a common problem that is often encountered in labor. It is one of the sources of labor safety and health problems. This problem cannot be underestimated since it could affect the declining labor productivity. Therefore, in order to reduce the occurrence of work fatigue, a serious action and prevention need to be done.

Kaliotik Lamongan Resto is a quite famous restaurant, mainly in Lamongan city. Highly customer visits lead to high demands for food production activities. Every day the food production process is done by workers; the production flow includes the preparation of raw materials, the process of cooking food and serving food. High production activities cause workers to potentially experience fatigue which can cause workplace accidents. According to the primary survey that has been done, the most annoyance that workers complain about is fatigue. This research aims to investigate the relationship of workload, work attitudes and nutritional status with work fatigue in the workforce at the Kaliotik Lamongan Resto.

\section{METHODS}

This study was a descriptive observational study which was done by applying a cross-sectional approach. The population in this study was all workers at the Kaliotik Lamongan Resto, which consisted of 13 people who worked in the kitchen and cashier kitchen section. The sampling technique used was the total population.

The data collection was started from March to October 2018. This research was done at J1. Raya Lamongan - Mantup KM 7, Lamongan. The techniques of data collection were done by collecting primary data and secondary data. The primary data collection was the questionnaire of respondent characteristics which included gender, age, and tenure, workload measurements were carried out by measuring the pulse rate of 10 beats and $\% \mathrm{CVL}$. Work attitude assessment was done by The Rapid Upper Limb Assessment (RULA) method, and work fatigue measurements were done by using the Reaction Timer tool. The secondary data collected was about the type of work and number of workers. Spearman correlation test was conducted to analyze the data by looking at the correlation coefficient to see the strength of the relationship. 


\section{RESULT}

\section{Characteristics of Respondents}

The characteristics of the Kaliotik Lamongan Resto workers include gender, age and working period. The results showed that the majority of Kaliotik Resto workers who were a female. That was about $62 \%$ or 8 people. The age of Kaliotik Resto workers' was mostly between the ages of 20-30 years, with the number of $54 \%$ or 7 people and most Kaliotik Resto workers had a period work $>1$ year which is equal to $77 \%$ or 10 people.

\section{Respondent's Workload Distribution}

The results showed that $61.5 \%$ or 8 Kaliotic Resto workers were included in the category which requires improvements to the workload.

\section{Respondents' Work Attitudes Distribution}

Based on table 2, 5 or $38.5 \%$ of the respondents were included in the category that needed further investigation, there might be a need for improvement of work attitudes. For about 4 or $30.7 \%$ of the respondents included in the category that needed an immediate investigation and improvement, then 2 or $15.4 \%$ of respondents are in the category that needed an investigation and repairs as soon as possible, and about 2 or $15.4 \%$ of respondents are in the category which did not have problems with posture during work.

\section{Respondents' Work Fatigue Distribution}

The results showed that among all workers who suffered from fatigue; $46.2 \%$ or 6 Kaliotik Resto workers were included in the category of mild fatigue. Also, $53.8 \%$ or 7 Kaliotik Resto workers were included in the category of normal fatigue levels.

Tabel 1. Distribution Respondents' based on Workload in Kaliotik Lamongan Restaurant in August 2018

\begin{tabular}{ccc}
\hline Workload & Frequency (n) & Percentage (\%) \\
\hline $\begin{array}{c}\text { Did not Experience } \\
\text { Fatigue }\end{array}$ & 5 & $38.5 \%$ \\
Needed Repairs & 8 & $61.5 \%$ \\
\hline Total & 13 & $100 \%$ \\
\hline
\end{tabular}

\section{Correlation Analysis of Workload and Work Fatigue}

The results of cross-tabulation in table 4 showed that there were $62.5 \%$ of respondents who experienced light work fatigue were included in the category which required improvements toward the workload. Furthermore, for about $37.5 \%$ of workers were in the normal levels of fatigue which were included in the category that needed improvements for their workload.

The results of the analysis of workload and work fatigue relationship obtained a correlation coefficient value of 0.415 , which means workload variables and work fatigue on laborers of Kaliotik Lamongan Resto indicated a moderate relationship.

\section{Correlation Analysis of Work Attitudes and Work Fatigue}

Depended on the result of cross-tabulation in table 5 the results shows that 3 or $75 \%$ of respondents experience mild fatigue that is in the

Tabel 2. Distribution Respondents' based on Work Attitude in Kaliotik Lamongan Restaurant in August 2018

\begin{tabular}{cccc}
\hline $\begin{array}{c}\text { Work Attitude (Level } \\
\text { of MSDs Risk) }\end{array}$ & Score & $\begin{array}{c}\text { Frequency } \\
\text { (n) }\end{array}$ & $\begin{array}{c}\text { Percentage } \\
\text { (\%) }\end{array}$ \\
\hline $\begin{array}{c}\text { Negligible risk, } \\
\text { acceptable posture } \\
\text { Low risk, further } \\
\text { investigation change } \\
\text { may be needed }\end{array}$ & $1-2$ & 2 & $15.4 \%$ \\
$\begin{array}{c}\text { Medium risk, further } \\
\text { investigation, change } \\
\text { soon }\end{array}$ & 5 & 5 & $38.5 \%$ \\
$\begin{array}{c}\text { Very high risk, } \\
\text { investigate and }\end{array}$ & $6+$ & 4 & $30.7 \%$ \\
implement change \\
now
\end{tabular}

Tabel 3. Distribution Respondents' based on Fatigue Level in Kaliotik Lamongan Restaurant in August 2018

\begin{tabular}{ccc}
\hline Fatigue Level & Frequency (n) & Percentage (\%) \\
\hline Normal & 7 & $53.8 \%$ \\
Mild Work Fatigue & 6 & $46.2 \%$ \\
\hline Total & 13 & $100 \%$ \\
\hline
\end{tabular}


Tabel 4. Cross Tabulation betweeen Workload and Work Fatigue in The Worker of Kaliotik Lamongan Restaurant in Agustus 2018

\begin{tabular}{|c|c|c|c|c|c|c|}
\hline \multirow{3}{*}{ Workload } & \multicolumn{4}{|c|}{ Work Fatigue } & \multirow{2}{*}{\multicolumn{2}{|c|}{ Total }} \\
\hline & \multicolumn{2}{|c|}{ Normal } & \multicolumn{2}{|c|}{ Mild } & & \\
\hline & $\mathbf{n}$ & $\%$ & $\mathbf{n}$ & $\%$ & $\mathbf{N}$ & $\%$ \\
\hline $\begin{array}{c}\text { Did not Experience } \\
\text { Fatigue }\end{array}$ & 4 & 80 & 1 & 20 & 5 & 100 \\
\hline Needed Repairs & 3 & 38 & 5 & 62 & 8 & 100 \\
\hline
\end{tabular}

Tabel 5. Cross Tabulation betweeen Work Attitudes and Work Fatigue in The Worker of Kaliotik Lamongan Restaurant in Agustus 2018

\begin{tabular}{|c|c|c|c|c|c|c|}
\hline \multirow{3}{*}{$\begin{array}{c}\text { Work Attitude } \\
\text { (Level of MSDs } \\
\text { Risk) }\end{array}$} & \multicolumn{4}{|c|}{ Work Fatigue } & \multirow{2}{*}{\multicolumn{2}{|c|}{ Total }} \\
\hline & \multicolumn{2}{|c|}{ Normal } & \multicolumn{2}{|c|}{ Mild } & & \\
\hline & $\mathbf{n}$ & $\%$ & $\mathbf{n}$ & $\%$ & $\mathbf{N}$ & $\%$ \\
\hline $\begin{array}{l}\text { Negligible risk, } \\
\text { acceptable posture }\end{array}$ & 2 & 100 & 0 & 0 & 2 & 100 \\
\hline $\begin{array}{l}\text { Low risk, further } \\
\text { investigation } \\
\text { change may be } \\
\text { needed }\end{array}$ & 3 & 60 & 2 & 40 & 5 & 100 \\
\hline $\begin{array}{l}\text { Medium } \\
\text { risk, further } \\
\text { investigation, } \\
\text { change soon }\end{array}$ & 1 & 25 & 3 & 75 & 4 & 100 \\
\hline $\begin{array}{c}\text { Very high risk, } \\
\text { investigate and } \\
\text { implement change } \\
\text { now }\end{array}$ & 1 & 50 & 1 & 50 & 2 & 100 \\
\hline
\end{tabular}

category of work attitudes which required to have an investigation and improvement immediately. For about 2 or $40 \%$ of respondents who experience mild fatigue are in the category that needed further investigation, and 1 or $50 \%$ of the respondent is in the category of investigation and improvement needed as soon as possible.

As a result of statistical tests of a strong relationship, work attitude and fatigue obtained the correlation coefficient value of 0.389 . This value indicates a weak relationship between work attitudes and work-fatigue in the workforce at the Kaliotik Lamongan Resto.

\section{DISCUSSION}

\section{Workload}

The workload is a difference between the capacity or ability of workers with the work demands. Physical workload measurement is done by measuring the heart rate during work. Measurement of heart rate during work is a method to assess cardiovascular strain. The measurement of the heart rate is done by checking the pulse of the radial artery at the wrist. An increasing pulse is influenced by the physical workload that determined by the number of muscles involved and the static load received, and also the temperature pressure from the work environment; the pulse will immediately change in tune with changes in loading (Tarwaka, 2015).

The Kaliotik Resto workforces have different tasks according to each section. As a cashier, the work carried out is to handle customer payment transactions and record the orders. While a waiter's chores are to note the orders, serve them to customers, carry back dirty stuff to the kitchen, clean the table, tidy up the customer's seat and clean the restaurant. Whereas the kitchen section has a responsibility to prepare the dish, process the orders, and also clean the kitchen as well as clean the whole restaurant. According to the chores description, it can be seen that the workforce in the kitchen section receive a quite heavy workload since they need to be always in a standing position. Moreover, the workers in the kitchen section have often exposed the heat from the stove as well as lifting food ingredients to be processed.

Based on the result of the study, it can be seen that in most workers, a number of 8 or $61.5 \%$ included in the category which needs to be fixed, and 5 or $38.5 \%$ of the workforce did not experience fatigue. The Kaliotik restaurant workers who are included in the category that needs to be fixed are mostly workers that work in the kitchen section. Similar to the research conducted by Kusgiyanto, et al (2017) which stated that excessive workload will lead to work fatigue, resulting from a significant relationship between workload and work fatigue in laborers making lumpia in Kranggan Village, Central Semarang District in 2017. For about 32\% of workers who have heavy workload experience severe levels of fatigue.

An improvement which can be done by the restaurant is to provide a workforce with special skill in the cleaning service section to reduce the workload on the kitchen and waiters so that they do not experience work fatigue.

\section{Work Attitude}

One of the parameters used in order to assess complaints in term of the musculoskeletal system is by assessing the work attitudes or work postures. 
There are several methods that can be used to assess work attitudes, one of them is The Rapid Upper Limb Assessment (RULA) method.

The result of the research toward work attitude of Kaliotik Lamongan Resto workers, which was done by applying The Rapid Upper Limb Assessment (RULA) method, showed that 5 or $38.5 \%$ of respondents included into a category which needs further investigation; 4 or $30.7 \%$ of respondents are in the category which needs an investigation and immediate repairs; 2 or $15.4 \%$ of respondents are in the category that requires an investigation and improvement as soon as possible.

An investigation that can be done is by evaluating work tools and workstations used by workers which lead to the formation of nonergonomic work attitudes, for instance when the waiter delivers an order to customers by carrying a tray containing the order, then a bent backward posture is formed.

In the kitchen section, the low height and the shape of the table that resembles a shelf, causes a posture to be bent on labor when preparing food.

Corrective actions which can be done to prevent the formation of non-ergonomic postures are by providing assistive devices in the form of trolley stand and adjusting the work desk design in accordance with the height of the workforce in the kitchen section.

The similar idea is also proposed by Arminas (2016) through her research concerning the designed work facilities and improved work postures in the manual activity of material handling for employees of the Makassar electronic mega mas shop. The research showed that manual lifting activities done by the workers could risk them at level 3, which is an immediate investigation and improvement needed.

Tarwaka (2015) stated that unnatural working attitudes cause the body's position to move away from its natural position, such as bending back, raised hands, etc. This unnatural work attitude is generally caused by the demands of work, work tools and workstations that are not in accordance with the abilities and limitations of workers.

\section{Work Fatigue}

Work fatigue measurement is done by using a reaction timer with a light stimulus. In a state of fatigue, the ability of the workforce in order to give responses will take longer time. The more tired they are, the longer the time needed to react (Tarwaka, 2015).
According to the result of this study, the level of work fatigue which is experienced by the Kaliotik Resto workforce is mild work fatigue which is 6 or $42.6 \%$, while 7 or $57.4 \%$ of the workforce does not experience fatigue. Most workers who experience fatigue are those who work as kitchen and waiter sections, meanwhile, the cashier section does not.

The result of this study indicates a consistency along with the research that was conducted by Shinta (2013) toward the relationship of individual factors with fatigue in tofu makers at the tofu factory in Jomblang Village, Candisari District, Semarang in 2013. The overall result of fatigue measurement which was done by using the reaction timer on factory workers is mild fatigue.

Tarwaka (2015) stated that someone could easily experience fatigue due to several factors including the intensity of physical and mental work duration, work environments such as climate and lighting conditions, circadian rhythm, physical problems such as pain and health conditions, and nutrition.

Maurits (2010) stated that there should be enough rest between hours of work. It is going to be better if the workers are not handed stressful and heavy workloads in long term. Other than that, a refreshing activity, such as a vacation, should be organized to reduce the stress level and restore work enthusiasm.

\section{Correlation Analysis of Workload and Work Fatigue}

According to the results of the study, some of the workers who experienced light work fatigue were included in the category which required an improvement toward the workload. The Spearman correlation test was done to see the strength of the relationship obtained by the correlation coefficient which resulting 0.415 . The number resulted from those test indicated that the workload and work fatigue possessed a moderate relationship.

The results of this study were supported by research conducted by Nurjannah, et al (2014) regarding the relationship between workload and work fatigue on the employees who worked in cutting section of PT. Dan Liris Banaran, Sukoharjo Regency. The results of the study showed that there was a significant relationship toward the low strength relationship between workload and fatigue.

An excessive workload potentially leads to a reduction of oxygen levels in the body, resulting from work fatigue (Suma'mur, 2009).

The theory of Suma'mur (2009) stated that the volume of work which is charged to labor 
becomes his/her responsibility; a workforce receives a burden as a result of physical activity he/ she has been carried out. A heavy work requires a frequent rest and short working time. In case, the working duration is added; it is going to exceed the ability of the workforce which induce work fatigue. A workforce has its own abilities in relation to workload, some of them are more suitable for physical workload and so on.

However, as a general equation, a person is only able to bear the burden on a certain weight. This is the purpose of placing the right workforce for a certain job. Several points which could be a reference or benchmark in order to transmit an order are depended on suitability, experiences, skills, motivation, and so on.

\section{Correlation Analysis of Work Attitudes and Work Fatigue}

This study has discovered the value of the contingency coefficient of 0.389 , resulting from statistical test analysis using the Spearman correlation test; which means that work attitude indicates a weak relationship toward work fatigue.

Certain sections at the Kaliotik Resto also indicate odd and unnatural working attitudes, for instance, in the waiter section, the waiter's body posture will look back with shoulders raised while delivering an order to customers. The amount of the load that is carried upon the tray affects the natural posture.

Unnatural work attitude is also shown by the chefs and baristas, such as a bent posture while preparing dishes. The unnatural posture is influenced by a non-ergonomic work table the worker used, which the height of the table is not in accordance with the height of the workforce.

This same result is also performed by Nugroho, et al (2015) research on laundry workers at north purwokerto district Banyumas Regency. His research discovered that most workers also experiencing moderate and severe fatigue due to non-ergonomic working attitudes.

Through Tarwaka (2015) stated that unnatural working attitudes leads the body's position to move away from its natural position, such as bending back, raised hands, etc. In most cases, this unnatural working attitude is caused by work demands, work tools and workstations that are not in accordance with the abilities and limitations of workers.

In her research, Amalia (2017) asserted that work attitude is a determining point in analyzing the effectiveness of a job. If the posture of the workers is good and ergonomic, it can be ascertained that the results obtained will be good, however, if the work posture is not good then the workers will easily experience fatigue.

\section{CONCLUSION}

Based on the result of research conducted, it can be concluded that $61.5 \%$ of the Kaliotik Resto workers were in the category which requires improvements toward their workload. Meanwhile, the work attitude of Kaliotik Resto workers is categorized in level $2(38.5 \%)$, which requires further investigation and improvement. Most of the fatigue experienced by Kaliotik Resto workers is mild fatigue, with the number of $42.6 \%$. There is a correlation between workload and work fatigue with moderate strength of the relationship. Whereas the work attitude possesses a weak strength of relationship toward work fatigue at Kaliotik Lamongan Resto workers.

Therefore, according to the brief explanation above, the conclusion is the main factor that causes work fatigue is an excessive workload, while work attitude is not a factor of work fatigue. As a suggestion, the restaurant owner could add the number of workers in the cleaning service section, and provide more trolley stands for waiters.

\section{ACKNOWLEDGEMENT}

The author would like to thank the Lamongan Kaliotik Resto for their cooperation in the research process. The author also expresses her gratitude to Mr Mulyono, S.KM., M.Kes who have provided guidance and advice until the completion of this scientific paper.

\section{REFERENCES}

Amalia, N. R., Wahyuni, I. and Ekawati (2017) 'Hubungan Postur Kerja dengan Keluhan Kelelahan Kerja pada Operator Container Crane PT. Terminal Peti Kemas Semarang', Jurnal Kesehatan Masyarakat (e-Journal), 5(5), pp. 290-298.

Arminas (2016) 'Perancangan Fasilitas Kerja Dan Perbaikan Postur Kerja Pada Aktivitas Manual Material Handling Karyawan Toko Mega Mas Elektronik Makassar.', Jurnal Ergonomi dan K3 (e-journal), 1(1), pp. 34-42. 
Atiqoh, J., Wahyuni, I. and Lestyanto, D. (2014) 'Faktor-Faktor yang Berhubungan dengan Kelelahan Kerja pada Pekerja Konveksi Bagian Penjahitan di CV. Aneka Garment Gunungpati Semarang', Jurnal Kesehatan Masyarakat, 2(2), pp. 119-126.

Kusgiyanto, W., Suroto, S. and Ekawati, E. (2017) 'Analisis Hubungan Beban Kerja Fisik, Masa Kerja, Usia, Dan Jenis Kelamin Terhadap Tingkat Kelelahan Kerja Pada Pekerja Bagian Pembuatan Kulit Lumpia Di Kelurahan Kranggan Kecamatan Semarang Tengah', Jurnal Kesehatan Masyarakat (e-Journal), 5(5), pp. 413-423.

Maharja, R. (2015) 'Analsys of Level of Work Fatigue based on Physical Workload of the Nurses in Inpatient Care Unit of RSU Haji Surabaya', The Indonesian Journal of Occupational Safety and Health, 4(1), pp. 93-102.

Maurits, L. S. (2010) Selintas Tentang Kelelahan Kerja. Yogyakarta. Yogyakarta: Amara Books.

Nugroho, G. K. T., Ulfah, N. and Harwanti, S. (2015) 'Hubungan Sikap Kerja Dengan Kelelahan Kerja Pada Pekerja Laundry Di Kecamatan Purwokerto
Utara Kabupaten Banyumas', Jurnal Kesmasindo, 7(3), pp. 209-218.

Nurjannah, Hardjanto and Suwadji (2014) 'Hubungan Antara Beban Kerja Dengan Kelelahan Kerja Pada Karyawan Bagian Cutting PT. Dan Liris Banaran Kabupaten Sukoharjo', Kesehatan Masyarakat, pp. 1-14.

Shinta, D. A. K. (2013) The Correlation between Individual Factor with Fatigue in Tahu Factory Worker in Jomblang Village, Candisari Sub District Semarang City 2013. Undergraduate Thesis. Semarang: Faculty of Health Science Universitas Dian Nuswantara.

Suma'mur, P.K (2009) Corporate Hygiene and Occupational Health. Jakarta: CV Sagung Seto.

Tarwaka (2015) Ergonomi Industri, Dasar-dasar Pengetahuan dan Aplikasi di Tempat Kerja. Edisi Ke-2. Surakarta: Harapan Press.

Yuslistyari, E. I. and Setianah, P. (2018) 'Analisis Perbaikan Postur Kerja dengan Pendekatan Ergonomi pada Home Industri JKS Snack \& Catering di Serang-Banten', Journal Industrial Manufacturing, 3(1), pp. 51-56. 